\title{
Performance of Eggshell Powder Addition to Clay Soil for Stabilization
}

\author{
Reza Pahlevi Munirwan, Ramadhansyah Putra Jaya, Munirwansyah, Ruslan
}

\begin{abstract}
The behavior of clay soil often becomes problematic for the building above it. One problem is its shrinking and swelling behavior which is affected by its water content, which also frequently influences the soil bearing of capacity in holding the load of the building above it. The powder from eggshell which abbreviated as ESP is a food industry waste that is high calcium and not often used for reprocessing. This experiment purposes is to know the effect of adding ESP as a stabilizing material in clay. Soil sample for laboratory testing was carried out from Cot Bagie Village, Blang Bintang, Aceh Besar District, and Aceh Province. From AASHTO classification system, the soil sample is A-7-5 (21) and from USCS system, is organic clay with high plasticity $(\mathrm{OH})$. The percentages of ESP added are 0\%, 3\%, 6\% and $9 \%$ of the dry weight of the clay for experiment on laboratory. The Atterberg Limit parameters commonly incline with ESP addition. Based on the standard Proctor test, the original soil has an Optimum Moisture Content (OMC) of 19.8\% and a maximum dry unit weight $\left(\gamma_{d \text { max }}\right)$ of $1.367 \mathrm{gr} / \mathrm{cm}^{3}$. Overall, adding ESP to the clay sample increases the mechanical properties of soil compared to the sample without ESP. Thus, the use of ESP for stabilization in this experiment can improve the bearing capacity, so that it is beneficial for construction in the field.
\end{abstract}

\section{Keywords: Clay, Eggshell Powder, Soil, Stabilization}

\section{INTRODUCTION}

Soil behavior shows an important influence on the construction above it. Soil, as a material for construction, is applied as embankment material, which is collected from a borrow area, which is generally as clay cohesive soil. Clay behavior that is very sensitive to the water content addition and has a high shrink-swell characteristic as stated by [1]. Soil conditions that experience shrinkage can also affect the bearing capacity of the soil. Soil improvement efforts to increase soil bearing capacity by adding chemicals, industrial waste, and fiber materials have been carried out so far. [2] conducted a study on the addition of lime on clay so as to reduce the effect of soil shrinkage.[3] studied the addition of rubber fibers on clay which is then stabilized with cement. Furthermore, [4] also carried out expansive soil stabilization

Revised Manuscript Received on November 05, 2019.

* Correspondence Author

Reza Pahlevi Munirwan*, Department of Civil Engineering, Faculty of Engineering, Universitas Syiah Kuala, Banda Aceh, Indonesia. Email: r.munirwan@unsyiah.ac.id

Ramadhansyah Putra Jaya, Faculty of Civil Engineering Technology, Universiti Malaysia Pahang, Pahang, Malaysia. Email: ramadhansyah@ump.edu.my

Munirwansyah, Department of Civil Engineering, Faculty of Engineering, Universitas Syiah Kuala, Banda Aceh, Indonesia. Email: nir_geotechnical@unsyiah.ac.id

Ruslan, Department of Environmental Engineering, Universitas Serambi Mekkah, Banda Aceh, Indonesia. Email: ruslancivilengineer@gmail.com on sub-grade roads using lime. [5] conducted a study of the rice husk ash, lime and plastic fiber effect on silt soil parameters.

Eggshell powder (ESP), which is a food industry waste, has been considered as a material for clay mixture to increase soil bearing capacity and strength parameter of clay (Figure 1). The use of expensive lime requires further research to find a more economically friendly substitute for material with similar characteristics, which leads to the use of eggshell powder. In general, from previous studies on ESP, it was found to improve soil strength. With the correct mixing method and the good characteristics of ESP, it is expected to maximize the use of ESP in clay stabilization.

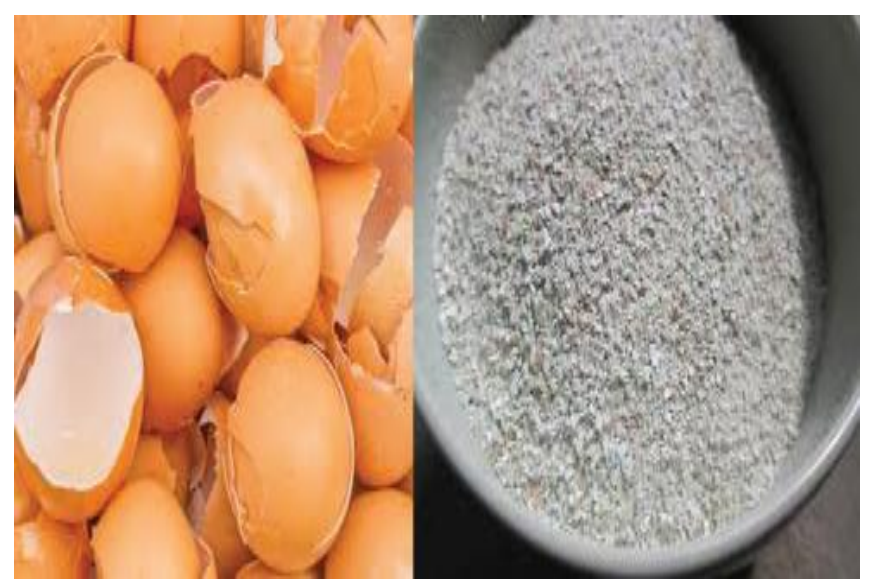

(a)

(b)

Figure 1. Eggshells (a) and egshell powder (b)

Research on the application of the agricultural and household industry wastes for geotechnics was carried out by [6]-[9]. According to them, the use of ESP in soil stabilization can replace the role of other lime-contained material, which has been more commonly used, due to the similarity in composition of the two. [10] tried to compare the effect of ESP substitution to the soil. However, it was concluded that with the same percentage of addition, the value of soil shear strength with lime addition is still better than ESP.

[11] tried to compare the effect of fly ash and ESP on CL soil for the USCS classification. Furthermore, [12] examined the addition of ESP to lateric soils stabilized with cement. The conclusion is that the parameter of shear strength of lateric soils can increase up to $35 \%$ compared to the original soil. [13] also examined the possibility of using ESP as a stabilization material for lateric soils as a sub-grade of road construction. 


\section{MATERIALS AND METHODS}

The clay used in this study came from the Cot Bagie area, Blang Bintang Subdistrict, Aceh Besar District, Aceh Province. The reason for collecting the clay samples from here is that because this location is often used for land reclamation in building and road construction in Aceh Besar District and Banda Aceh City. Visually, this cohesive soil is not good to apply in road piles or buildings since cohesive soils have high shrinkage growth and weak bearing capacity. The condition of Aceh Province that is prone to earthquakes and earthquake-related disasters, as mentioned [14]-[15] require good construction materials to reduce failure possibility of construction and the achievement of the life expectancy of construction in accordance with the plan. Furthermore, planning based on security risk analysis must be applied to earthquake-prone areas [16].

The soil used in this study is A-7-5 with Group Index 21, which is high plasticity clay based on AASHTO method, and $\mathrm{OH}$ (Organic High), which is medium to high plasticity organic clay based on USCS classification with a specific gravity (SG) of 2.54. Visually, this soil is brownish red in color, has an adhesive and pliant characteristic when held. However, in a dry state, the soil feels very tough and strong, while in a wet state the soil will weaken and expand.

Table I: Chemical composition of eggshell powder (ESP)

\begin{tabular}{|l|c|}
\hline Chemical composition & Value (\%) \\
\hline Real Density (gr/cm3) & 2.47 \\
Hygroscopic Moisture (\%) & 1.1 \\
$\mathrm{pH}\left(\mathrm{H}_{2} \mathrm{O}\right)$ & 8.3 \\
Cation exchange capacity, & 9.52 \\
meq/100g content of soluble salts, & \\
$\mathrm{ppm}$ & 12.0 \\
$\mathrm{~K}$ & 50.2 \\
$\mathrm{Ca}$ & 12.0 \\
$\mathrm{Mg}$ & 0.0 \\
$\mathrm{Al}$ & 0.0 \\
$\mathrm{H}+\mathrm{Al}$ & 21.0 \\
$\mathrm{Na}$ & 5.36 \\
Organic Matter $(\%)$ & 3.11 \\
Organic Carbon $(\%)$ & 39.0 \\
$\mathrm{~S}_{-} \mathrm{SO}_{4}$ Content $(\mathrm{ppm})$ & \\
\hline
\end{tabular}

Details of the chemical composition of eggshell powders can be seen in Table 1 which shows a calcium content of more than 50\%. Egg shells, as cited in [17] contain around $96 \%$ calcium carbonate, $1 \%$ calcium phosphate, $1 \%$ magnesium carbonate, and other organic materials as well as water. Furthermore, [18] explained that egg shells are environmentally friendly, inexpensive, and available in abundance. The egg shells are then cleaned and dried in the sun to dry (see Figure 1a). Then the egg shells are mashed by pulverizing it into eggshell powder (ESP) which passes the number 200 sieve (see Figure 1b).

The method of the test began by mixing the soil with eggshell powder (ESP) evenly and adding water in accordance with the mix design. Then, the physical properties of the soil for all percentage mixes were examined, measuring the specific gravity (GS), measurement of soil water content (w), plastic limit (PL), liquid limit (LL), and distribution of filter analysis and hydrometer. The testing of the physical properties of the original soil found a liquid limit value of $65.28 \%$ and a plastic limit value of $34.83 \%$. The \# 200 pass filter analysis found a value of $96.97 \%$. The results of the complete physical properties test are presented in Table 2.

Table II: Physical testing and compaction test results

\begin{tabular}{|c|c|c|c|c|}
\hline \multirow{2}{*}{ Test parameter } & \multicolumn{4}{|c|}{ Mixture percentage } \\
\hline & $0 \%$ & $3 \%$ & $6 \%$ & $9 \%$ \\
\hline Specific gravity & 2.46 & 2.79 & 2.21 & 2.32 \\
\hline Liquid limit (\%) & 65.28 & 64.99 & 57.8 & 63.15 \\
\hline Plastic limit (\%) & 34.83 & 36.11 & 36.02 & 32.13 \\
\hline Plasticity index (\%) & 30.45 & 28.88 & 21.78 & 31.03 \\
\hline \#200 pass filter $(\%)$ & 96.97 & 96.33 & 95.13 & 97.23 \\
\hline Group Index & 37 & 35 & 31 & 37 \\
\hline $\begin{array}{l}\text { Dry unit weight } \\
\left(\mathrm{gr} / \mathrm{cm}^{3}\right)\end{array}$ & 1.367 & 1.502 & 1.485 & 1.445 \\
\hline Water content $(\%)$ & 19.8 & 17.7 & 17.7 & 18.8 \\
\hline
\end{tabular}

\section{RESULTS AND DISCUSION}

Compaction testing is done using the Standard Proctor method in accordance with ASTM D-698. 6 samples of soil are prepared for each percentage, with a weight of $2 \mathrm{~kg}$ each, before being mixed with ESP for making compaction test samples. The total number of samples for compaction testing is 24 samples. Compaction test results on all percentages of soil mixtures with ESP can be seen in Figure 2.

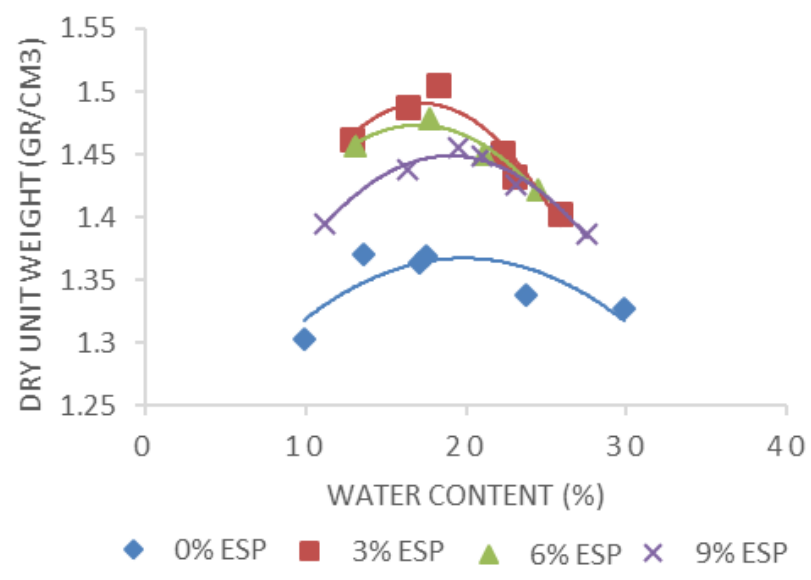

Figure 2. Soil compaction test results

Based on Figure 4(a) and 4(b), the results displayed that the addition of a mixture of various percentages of eggshell powder on the clay soil from Cot Bagie

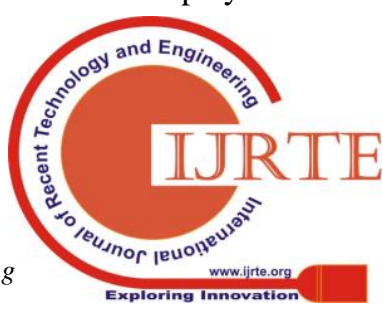


village in Blang Bintang Subdistrict affected the value of physical properties and compaction of the soil. The physical properties of Cot Bagie Village were reviewed based on Table 2, resulting in increased density at a percentage of $3 \%$ compared to original soil, but then decreased below the original soil for percentages of $6 \%$ and $9 \%$ with soil index values for all mixtures above 30 .

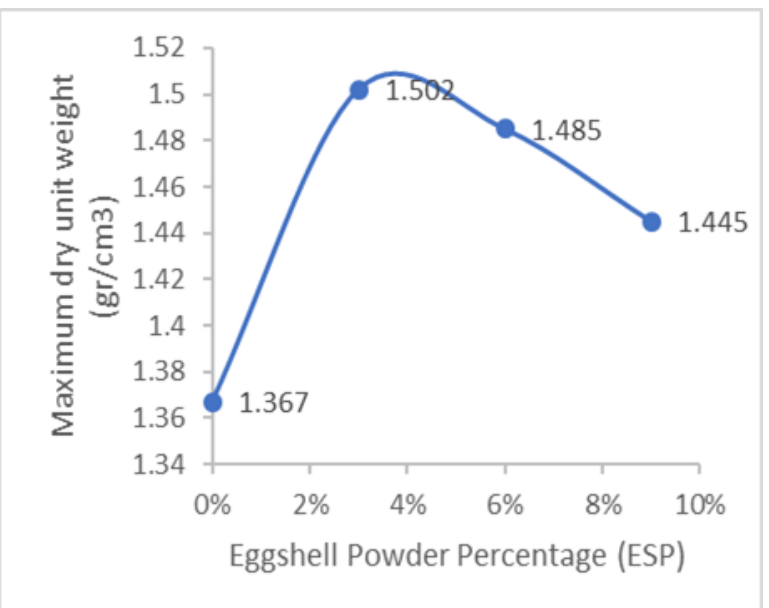

(a)

Figure 4(a). The effects of ESP addition to Compaction Parameter at dry unit weight

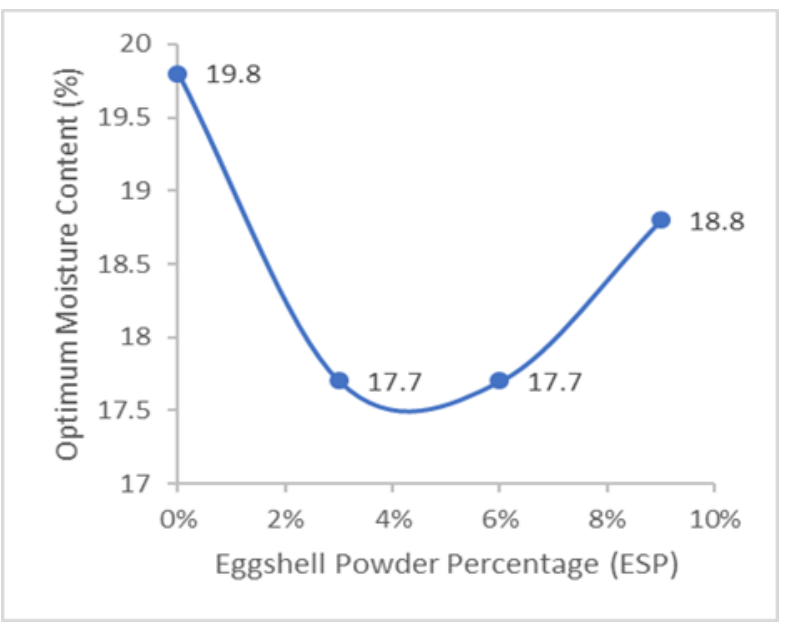

(b)

Figure 4(b). The effects of ESP addition to Compaction Parameter at optimum moisture content

From the direct shear results of soil in Figure 5(a) and 5(b), it can be seen that the parameter of soil cohesion increases with the addition of ESP. Similarly, the value of soil shear angle was also improved with ESP addition. The direct shear test was based on ASTM D 1452-80.

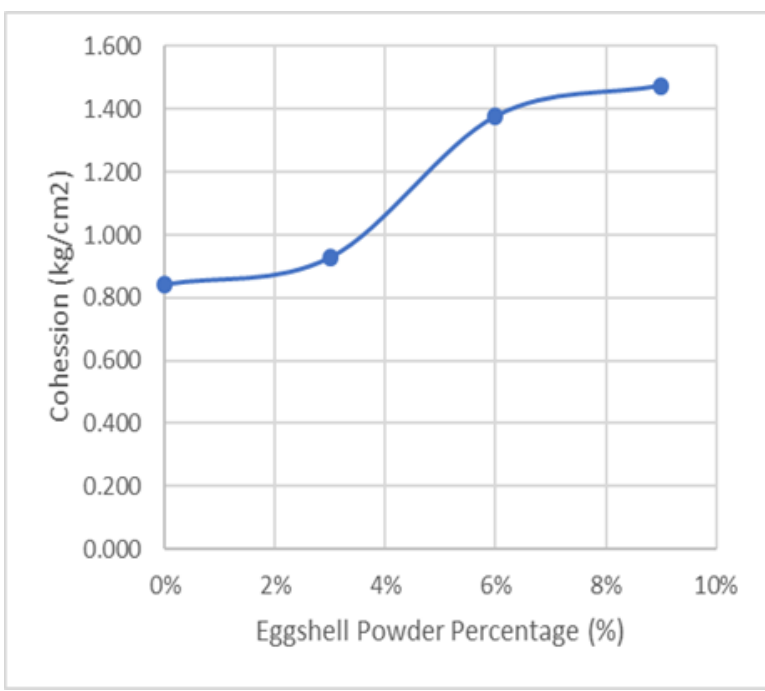

(a)

Figure 5(a). The effects of ESP addition to Soil Shear Strength Parameter for Cohession

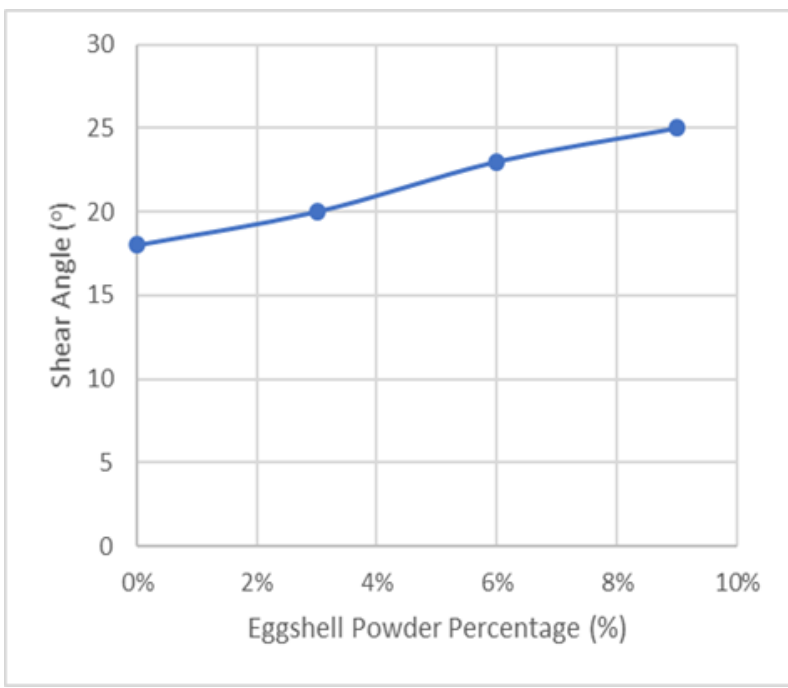

(b)

Figure 5(b). The effects of ESP addition to Soil Shear Strength Parameter for shear angle

\section{CONCLUSION}

Generally, clay is stabilized with eggshell powder (ESP) with increases in specific gravity for a low percentage of ESP and decreases for a higher percentage. The liquid limit value also showed a decrease with increasing ESP mixture. Atterberg Limit parameters generally decrease with increasing ESP. In general, the soil density of clay from Cot Bagie Village, Blang Bintang Subdistrict, decreases with $\mathrm{OMC}$ value, and the maximum dry unit weight increases at a low percentage of ESP (3\%) and decreases for $6 \%$ and $9 \%$. In general, with the increase of the percentage of ESP, the maximum dry unit weight of the soil and soil shear strength parameter were increase compared to the soil without ESP addition. Thus, the use of ESP for soil stabilization based on laboratory experimental research can improve soil bearing capacity for the better so that it is useful for construction in the field. 


\section{ACKNOWLEDGMENT}

Authors would like to thank you for Universitas Syiah Kuala under Indonesia Ministry of Research and Technology and Lembaga Penelitian dan Pengabdian Masyarakat (LPPM) Universitas Syiah Kuala Banda Aceh Indonesia for Research Scheme number 204/UN11.2/PP/PNBP/SP3/2019. Additionally, authors also thank for any supports and appreciate to soil mechanics laboratory staffs and assistants for all their help.

\section{REFERENCES}

1. Munirwansyah, R. P. Munirwan, M. Sungkar, F. Fachrurrazi, "Predicting Red Clay Swelling Behaviour of Jangka Buya-Pidie Jaya Earthquake Zone in Aceh", AIP Conference Proceedings, 2059 (1), 2019.

2. Munirwansyah, R. P. Munirwan, "Lime-Clay Stabilization to Modified the Characteristic of Mechanical Properties and Reduce the Swelling Sub Grade", The International Conference of Engineering and Science for Research and Development, Volume 1(1), 2016.

3. J. S. Yadav, S. K. Tiwari, "Effect of Waste rubber Fibres on the Geotechnical Properties of Clay Stabilized with Cement", Applied Clay Science, Volume 149, pp. 97-110, 2017.

4. Munirwansyah, R. P. Munirwan, "Stabilization on Expansive Soil for Road Subgrade for Geotechnic Disaster Approach", International Journal of Disaster Management, Volume 1(1), pp. 8-19, 2017.

5. A. S. Muntohar, A. Widianti, E. Hartono, W. Diana, "Engineering Properties of Silty Soil Stabilized with Lime and Rice Husk Ash and Reinforced with Waste Plastic Fiber", Journal of Materials in Civil Engineering, Volume 25, pp. 1260-1270, 2013.

6. A. V. Narasimha Rao, M. Chittaranjan, "Applications of Agricultural and Domestic Wastes in Geotechnical Applications: An Overview", Journal of Environmental Research and Development, Volume 5(3), pp. 673-678, 2011.

7. P. Pliya, D. Cree, "Limestone derived eggshell powder as a replacement in Portland cement mortar", Construction and Building Materials, Volume 95, pp. 1-9, 2015.

8. A. T. Sabu, M. R. Sharmila, "Experimental study on the stabilization of soil with environmental waste and coir fibres", International Journal of Civil Engineering and Technology, Volume 8(4), pp. 679-688, 2017.

9. O. E. Oluwatuyi, B. O, Adeola, E. A. Alhassan, E. S. Nnochiri, A. E. Modupe, O. O. Elemile, T. Obayanju, G. Akerele, "Ameliorating effect of milled eggshell on cement stabilized lateric soil for highway construction", Case Studies in Construction Materials, 2018.

10. O. O. Amu, A. B. Fajobi, B. O. Oke, "Effect of Eggshell Powder on the Stabilizing Potential of Lime on an Expansive Clay Soil", Research Journal of Agriculture and Biological Sciences, Volume 1(1), pp. 80-84, 2005.

11. W. Jassim, "Influences of Fly-ash and Eggshell Powder on Some of Engineering Properties of Al-Umara Soil", Journal of Engineering and Development, Volume 6(2), pp. 211-219, 2012.

12. U. N. Okonkwo, I. C. Odiong, E. E. Akpabio, "The Effects of Eggshell Ash on Strength Properties of Cement-stabilized Lateric", Volume 3(1), pp. 18-25, 2012

13. A. J. Olarewaju, M. O. Balogun, S. O. Akinlolu, "Suitability of Eggshell Stabilized Lateric Soil as Subgrade Material for Road Construction", Electronic Journal of Geotechnical Engineering, Volume 16, Bund. H, pp. 899-908, 2011.

14. R. P. Munirwan, H. Gunawan, "Evaluasi Potensi Likuifaksi Pesisir Pantai Krueng Raya Aceh Besar Provinsi Aceh", Jurnal Teknik Sipil Unsyiah, Volume 1(2), pp. 131-142, 2012.

15. M. Munirwansyah, R. P. Munirwan, H. Yunita, "Geotechnical Engineering Aspect Related to Pidie Jaya - Aceh Earthquake Disaster and Mitigation", International Journal on Advanced Science Engineering Information Technology, Volume 8(3), pp 870-875, 2018.

16. Munirwansyah, M. Irsyam, R. P. Munirwan, H. Yunita, M. Z. Usrina, "Geotechnical Approach for Occupational Safety Risk Analysis of Critical Slope in Open Pit Mining as Implication for Earthquake Hazard”, IOP Conference Series: Materials Science and Engineering, Volume 352, Conference 1, 2018.

17. A. Laca, A. Laca, M. Diaz, "Eggshell Waste as Catalyst: A Review", Journal of Environmental Management, Volume 197, pp. 351-359, 2017.
18. M. Bootklad, K. Kaewtatip, "Biodegradation of Thermoplastic Starch/ Eggshell Powder Composites", Carbohydrate Polymers, Volume 97(2), pp. $315-320,2013$.

\section{AUTHORS PROFILE}

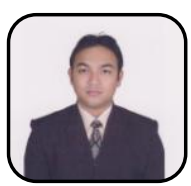

Reza Pahlevi Munirwan graduated from Civil Engineering of Universitas Syiah Kuala for bachelor degree and Geotechnical Engineering of University of Glasgow for master degree. He is now a full-time lecturer in Civil Engineering Department of Universitas Syiah Kuala

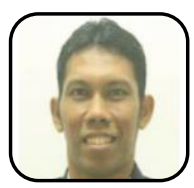

Ramadhansyah Putra Jaya has done B.Eng in Civil Engineering from Universitas Syiah Kuala, and Master and Doctoral study from Universiti Sains Malaysia. Currently, he is an Associate Professor in Universiti Malaysia Pahang - Malaysia.

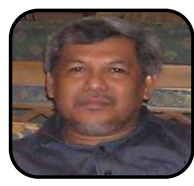

Munirwansyah is a full-time professor in Civil Engineering Department of Universitas Syiah Kuala, Banda Aceh, Indonesia. He was graduated from Universitas Syiah Kuala for bachelor degree, and Institut Teknologi Bandung for his master and doctoral degree.

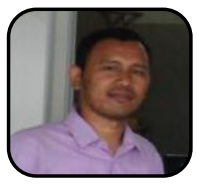

Ruslan is currently a Ph.D candidate for Civil Engineering Department of Universitas Syiah Kuala, Indonesia. He also finished his bachelor and master degree from Universitas Syiah Kuala, Banda Aceh, Inodnesia 